\title{
МИНЕРАЛЬНЫЕ ВКЛЮЧЕНИЯ В РЕТРОГРАДНЫХ ГРАНАТАХ ИЗ АРХЕЙСКИХ ГЛИНОЗЕМИСТО-ЖЕЛЕЗИСТЫХ ПОРОД ВОРОНЕЖ- СКОГО КРИСТАЛЛИЧЕСКОГО МАССИВА (ОСОБЕННОСТИ ВНУТРЕННЕГО СТРОЕНИЯ, УСЛОВИЯ КРИСТАЛЛИЗАЦИИ)
}

\author{
С. М. Пилюгин \\ Воронежский государственный университет \\ Поступила в редакцию 7 сентября 2018 г.
}

\begin{abstract}
Аннотация: в гранатах из архейских глиноземисто-железистых пород Воронежского кристаллического массива были обнаружены минеральные включения двух типов: твердофазные мономинеральные (пироксены, плагиоклаз, ииркон, калиевый полевой шпат, магнетит) и ретроградные полиминеральные. Полиминеральные включения представляют собой кристаллические минеральные системы сидерит-пирофиллитового состава. Наблюдаемые минеральные парагенезисы были сформированы в результате реакции: $\mathrm{Opx}+\mathrm{Pl}+\mathrm{H} 2 \mathrm{O}+\mathrm{CO} 2=>\mathrm{Grt}+\mathrm{Sd}+\operatorname{Prf} \pm \mathrm{Cpx} \pm \mathrm{Mag}$. Термометрические оценки кристаллизации граната, полученные по минеральным твердофазным включениям (GOp геотермометр) составляют $636 \pm 15^{\circ} \mathrm{C}$ (этап метаморфизма M3). Температура стабильности пирофиллит-сидеритовой ассочиаџии $\left(350\right.$ до $\left.550^{\circ} \mathrm{C}\right)$ может рассматриваться как нижняя гранииа этапа метаморфизма МЗ.
\end{abstract}

Ключевые слова: Архей, минеральные включения, гранат, глиноземисто-железистые породы.

\section{MINERAL INCLUSIONS IN RETROGRADE GARNETS FROM ARCHEAN ALUMINOUS IRON FORMATIONS OF THE VORONEZH CRYSTALLINE MASSIFS (FEATURES OF THE INTERNAL STRUCTURE, CRYSTALLIZATION CONDITIONS)}

\begin{abstract}
Archean aluminous iron formations of the Voronezh crystalline massif, mineral inclusions of two types were found: solid-phase monomineral (pyroxenes, plagioclase, zircon, potassium feldspar, magnetite) and retrograde polymineral. Polymineral inclusions are crystalline mineral systems of siderite-pyrophyllite composition. The observed mineral paragenesis were formed as a result of the reaction: $\mathrm{Opx}+\mathrm{Pl}+\mathrm{H} 2 \mathrm{O}+\mathrm{CO} 2=>\mathrm{Grt}+\mathrm{Sd}+\mathrm{Prf} \pm \mathrm{Cpx} \pm$ Mag. Thermometric estimates of garnet crystallization, obtained from mineral solid-phase inclusions (GOp geothermometry) are $636 \pm$ $15^{\circ} \mathrm{C}$ (the stage of metamorphism M3). The stability temperature of the pyrophyllite-siderite association $\left(350\right.$ to $550^{\circ} \mathrm{C}$ ) can be considered as the lower boundary of the M3 metamorphism stage.
\end{abstract}

Key words: Archean, mineral inclusions, garnet, aluminous iron formations.

\section{Введение}

Породы архейских метаморфических комплексов, претерпевших региональный метаморфизм, часто являются продуктами полистадийной перекристаллизации под воздействием флюида и меняющихся Т-Р условий.

Перекристаллизация может носить масштабный характер, в результате чего ранние минеральные парагенезисы сохраняются лишь фрагментарно в высокопрочных и термодинамически стабильных минералах. Именно поэтому реликтовые включения в минералах широко используются в метаморфической петрологии для восстановления физико-химической природы формирования пород $[1,2]$.

Учитывая широкое использование гранатов в количественных методах изучения горных пород (геотермобарометрия), а также широкую распространен- ность в них минеральных включений гранатсодержащие парагенезисы становятся незаменимыми при описании многих метаморфических комплексов. В качестве объекта изучения были выбраны архейские глиноземисто-железистые породы Воронежского кристаллического массива [3], содержащие большое количество кристаллов граната и претерпевшие в своей метаморфической истории несколько тектонотермальных ретроградных событий. Сопоставлением положения изохор углекислотных включений в минералах [4] с данными минералогической термобарометрии по равновесным составам минералов (ортоклинопироксенов, гранатов, плагиоклазов, биотитов) [5] ранее было установлено 3 метаморфических (тектоно-термальных) события: М1 - пиковый метаморфизм при $\mathrm{T}=1000 \pm 30^{\circ} \mathrm{C}, \mathrm{P}=10$ кбар, $\mathrm{D}$ (глубина) $=$ 36 км; М2 - T=705 $\pm 10^{\circ} \mathrm{C}, \mathrm{P}=4,2$ кбар, $\mathrm{D}=16$ км и 
$\operatorname{lgfO}_{2}=-16$ бар; $\mathrm{M} 3-\mathrm{T}=610 \pm 25^{\circ} \mathrm{C}, \mathrm{P}=3,3$ кбар, $\mathrm{D}=12$ км и $\operatorname{lgfO}{ }_{2}=-18,8$ бар.

\section{Геологическая обстановка}

Архейские железистые формации докембрия широко распространены в пределах Воронежского кри- сталлического массива (ВКМ), который вместе с Украинским щитом (рис. 1а, б, в) представляет один из трех кристаллических сегментов (Сарматия) Восточно-Европейского кратона [6]. ВКМ (размером приблизительно 600х800 км) относится к северовосточной части Сарматии и был отделен в фанерозое
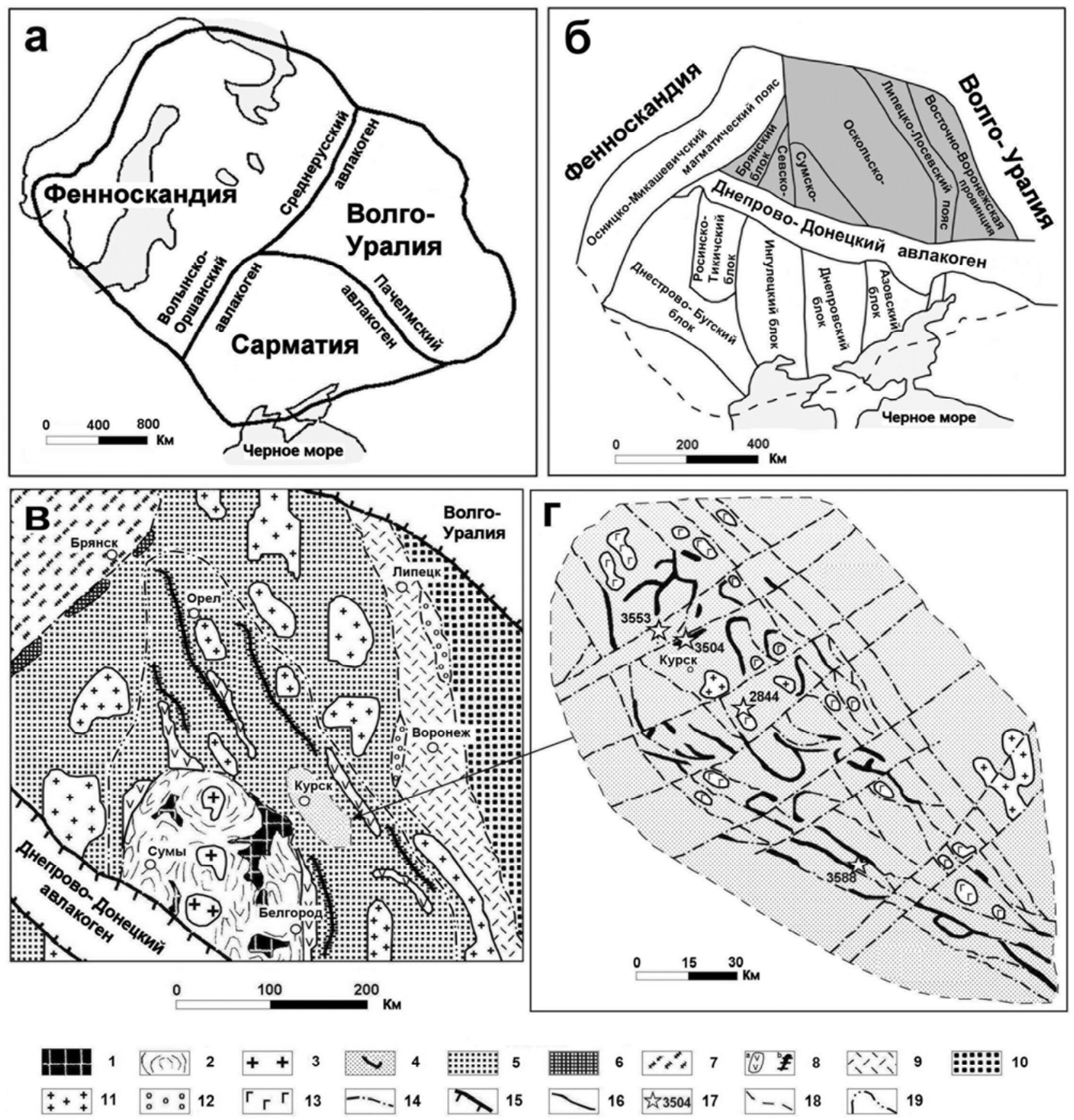

Puc. 1. $a$ - Три кристаллических сегмента Восточно-Европейского кратона [4]. $\sigma$ - Кристаллические домены Сарматии [6]. Воронежский кристаллический массив (ВКМ) выделен темным цветом. 8 - Схема геологического строения Воронежского кристаллического массива (по [7] с некоторыми изменениями). г - Курско-Бесединский гранулитовый блок ВКМ (район исследования). 1-6-Архей: 1 - зеленокаменные пояса; 2 - тоналит-трондьемитовые гнейсы и гранитоиды; 3 - поздне - и посттектонические гранитоиды; 4 - высокотемпературные метаморфические комплексы с железистыми формациями; 5 - полиметаморфические образования Обоянского комплекса (мигматиты и гнейсы с подчиненным количеством метабазитов -, регрессивно метаморфизованные в амфиболитовой фации; 6 - мафитовые интрузии (по геофизическим данным). 7-13 - Палеопротерозой: 7 гранулиты с возрастом 2,1 млрд.лет.; 8 - вулканогенно-осадочные формации, в том числе $a$ - вулканогенные и осадочные породы и $\sigma$ - железисто-кремнистые формации; 9 - метаморфизованные вулкано-плутонические комплексы; 10 - метаморфизованный 
терригенно-осадочный флишоидный комплекс; 11 - поздне - и посттектонические щелочные и полевошпатовые лейкократовые гранитоиды; 12 - полимиктовые конгломераты, осадочно-вулканогенные и терригенные породы; 13 - метагабброиды. 14 - Зоны глубинных разломов. 15 - Надвиговые зоны. 16 - Геологические границы. 17 - Местоположение скважин. 18 - Границы КурскоБесединского гранулитового блока. 19 - Район Курской магнитной аномалии.

от Украинского щита Днепрово-Донецким авлакогеном. На востоке, Липецко-Лосевский вулканогенный пояс и Восточно-Воронежская провинция разделяют ВКМ и Волго-Уральский кристаллический сегмент (рис. 1б, в). Согласно геохронологическим данным [7] в пределах ВКМ развиты различные архейские (от мезо- до позднеархейских) и палеопротерозойские образования. Архейские породы, метаморфизованные в условиях гранулитовой фации, присутствуют в регионе в виде кристаллических «блоков», состоящих из чередования (от 1-2 до 30-35 м мощностью) железистых пород (магнетитовых кварцитов и глиноземистожелезистых пород), метабазитов, метаультрабазитов и метапелитов. Эти «блоки» (реликты) локализованы среди мигматитов и гнейсов нерасчлененного обоянского архейского комплекса (рис. 1 в, г), развитого в центральной части ВКМ (Оскольский домен) и метаморфизованного преимущественно в регрессивной амфиболитовой фации. Гранулитовый комплекс маркируется интенсивными магнитными аномалиями, и был изучен, главным образом, буровыми скважинами глубиной 100-800 м.

Наиболее распространены железистые формации палеопротерозойского возраста, которые отнесены к курской серии (например, КМА). Архейские железистые формации относительно редки и встречаются в виде удлиненных тел (положительные магнитные аномалии) протяженностью до 10 км и шириной не более 100 м. Их мезоархейский возраст (2819 \pm 6 млн. лет) [8] подтвержден геохронологическими определениями по монациту (U-Pb изохронный метод) из метапелитовых гранулитов, переслаивающихся в разрезе с железистыми кварцитами. Данное значение соответствует последнему из проявленных в пределах этого блока высокотемпературных метаморфических событий, в результате которого образовались наблюдаемые минеральные парагенезисы и реакционные структуры.

\section{Методы исследования}

Bce образцы глиноземисто-железистых пород представляют собой керн скважин, который был детально описан при проведении полевых работ. Наиболее представительные образцы с гранатсодержащими ассоциациями были изучены на оптическом (Альтами ПОЛАР 3) и электронном микроскопе Jeol6380 LV (лаборатория ЦКПНО ВГУ). Состав минеральных фаз определялись при помощи полупроводникового детектора INCA Energy -250 смонтированного на электронном микроскопе. Условия анализа: ускоряющее напряжение 20 кВ, ток зонда 10-15 нА, время набора спектра 70 сек, диаметр электронного пучка в приповерхностном слое образца обычно равнялся 3-5 мкм. ZAF коррекция при расчете содержания окислов и оценка точности проводились с помо- щью комплекта программ математического обеспечения системы. Точность анализа систематически контролировалась по эталонным образцам природных и синтетических минералов. Микрозондовые определения составов твердофазовых включений и минералахозяина проводились в прозрачно-полированных шлифах после их детального изучения на оптическом микроскопе.

Всего было исследовано 12 образцов, минералы из 5 образцов (скважины 2844, 3588) были проанализированы на микрозонде (в среднем было выполнено по 20-30 локальных определений для каждого образца). Расчет формул минералов проводился с учетом координационных позиций катионов в формуле минерала. Кристаллохимические формулы граната рассчитаны на 12, пироксена на 6, пирофиллита на 10 атомов кислорода. Расчеты Р-Т условий метаморфизма проводились с помощью компьютерной программы TPF [9], оптимизация данных, полученных в результате микрозондовых анализов, была проведена на базе программ «MinFile» и «MultiEditor».

\section{Петрография и минералогия пород}

Глиноземисто-железистые породы представлены мелко- и среднезернистыми меланократовыми и мезократовыми породами с массивной или слабо линзовидно-полосчатой текстурой. Микроструктура породы неравномернозернистая порфиробластовая за счет крупных выделений граната (реже ортопироксена), иногда равномернозернистая, гранобластовая. Полосчатые текстуры обусловлены ориентированным расположением минералов в виде чередующихся, часто прерывистых полос мощностью от первых миллиметров до 3-4 см. В породе всегда присутствует гранат (20-60\%), кварц (10-20\%), магнетит (5-15\%), плагиоклаз (20-30\%), ортопироксен (10-20\%), реже встречается клинопироксен (5-10\%), калиевый полевой шпат (2-5\%), биотит (2-5\%), шпинель $(<3 \%)$.

Средний химический состав глиноземистожелезистых пород (мас.\%) соответствует (обр. 2844192, 2844-193, 2844-189): $\mathrm{SiO}_{2}-66,07, \mathrm{TiO}_{2}-0,19$; $\mathrm{Al}_{2} \mathrm{O}_{3}-4,06, \mathrm{Fe}_{2} \mathrm{O}_{3}-23,06, \mathrm{MnO}-0,3, \mathrm{CaO}-1,92, \mathrm{MgO}$ $-2,31, \mathrm{Na}_{2} \mathrm{O}-0,37, \mathrm{~K}_{2} \mathrm{O}-0,2$ (РФА, ИГЕМ РАН).

Гранат в глиноземисто-железистых породах часто образует скопления и, в зависимости от степени перекристаллизации пород и их деформированности, присутствует в них в двух основных формах. В первом случае это крупные (500 мкм и более) равномернозернистые гранобластовые агрегаты тесно расположенных или сросшихся зерен (обр. 2844-187, 2844$189,3588-255)$ (рис. 2). Облик минерала, свежий не трещиноватый. Во втором случае (обр. 2844-192) гранат (200-500 мкм) носит четко выраженный коронарный характер, развиваясь вокруг лейст плагиоклаза и, реже, пироксенов (рис. 2). Железистость граната в 
различных образцах варьирует от $0,81-0,86$ до 0,89 0,95 (альмандин) при содержании $\mathrm{CaO}$ от 1,5-3,7 до 7,6-8,6 мас.\% (табл. 1). В минерале проявлена слабая ретроградная зональность, выраженная в понижении магнезиальности от центров к краям зёрен, контактирующих с Fe-Mg минералами. У контакта граната с плагиоклазом обычно наблюдается возрастание гроссулярового минала при закономерном снижении $\mathrm{CaO}$ в плагиоклазе.

Ортопироксен, светлый со слабым плеохроизмом, присутствует в глиноземисто-железистых породах в виде крупных (500 мкм) субидиоморфных выделений с существенно более тонким агрегатом клинопироксена и кварца (рис. 2). В некоторых случаях в минерале отмечаются ламели клинопироксена (структуры распада твердых растворов), также указывающие на ретроградную перекристаллизацию породы. Железистость ортопироксена от 0,68-0,7 до 0,72-0,75 при относительно низком содержании $\mathrm{Al}_{2} \mathrm{O}_{3}$ от $0,3-0,6$ до 0,7-0,9 мас.\% (табл. 1).

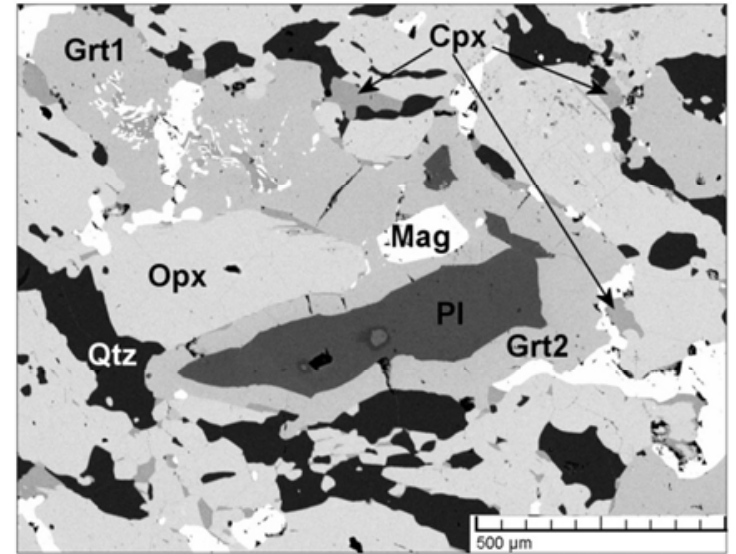

Puc. 2. Минеральные ассоциации глиноземистожелезистых пород ВКМ (изображения в обратно-отраженных электронах). Grt1 - порфиробласты граната содержащие минеральные включения магнетита (Mag) и клинопироксена (Cpx); Grt2 - коронарный гранат на границе плагиоклаза (Pl) и ортопироксена (Орх). Образец № 2844-192.

Таблица 1

Химические составы гранатов и содержашихся в них минеральных включений

\begin{tabular}{|c|c|c|c|c|c|c|c|c|c|}
\hline Образец & \multicolumn{4}{|c|}{193} & \multicolumn{3}{|c|}{189} & \multicolumn{2}{|c|}{192} \\
\hline Минерал & Grt* & Opx & Prf & Prf & Grt & Opx & Prf & Grt & Opx \\
\hline $\begin{array}{c}\text { Положение } \\
\text { в породе }\end{array}$ & матрица & $\begin{array}{c}\text { включе- } \\
\text { ние }\end{array}$ & $\begin{array}{l}\text { вклю- } \\
\text { чение }\end{array}$ & $\begin{array}{l}\text { вклю- } \\
\text { чение }\end{array}$ & матрица & $\begin{array}{l}\text { вклю- } \\
\text { чение }\end{array}$ & $\begin{array}{l}\text { вклю- } \\
\text { чение }\end{array}$ & матрица & $\begin{array}{l}\text { вклю- } \\
\text { чение }\end{array}$ \\
\hline Номер анализа & 5 & 7 & 1 & 3 & 20 & 8 & 18 & 9 & 13 \\
\hline $\mathrm{SiO}_{2}$ & 37,44 & 48,50 & 64,58 & 65,25 & 36,54 & 48,03 & 66,26 & 36,22 & 47,39 \\
\hline $\mathrm{Al}_{2} \mathrm{O}_{3}$ & 20,72 & 0,68 & 29,27 & 28,2 & 21,15 & 0,67 & 27,61 & 20,18 & 0,52 \\
\hline $\mathrm{Cr}_{2} \mathrm{O}_{3}$ & - & - & - & - & - & - & - & 0,14 & 0,09 \\
\hline $\mathrm{FeO}$ & 33,34 & 39,23 & 1,93 & 1,98 & 34,64 & 40,25 & 1,12 & 32,69 & 41,99 \\
\hline $\mathrm{MnO}$ & 1,7 & 0,65 & 0,42 & - & 1,42 & 0,71 & - & 1,94 & 0,71 \\
\hline $\mathrm{MgO}$ & 1,58 & 10,00 & - & - & 2,12 & 10,01 & - & 1,68 & 8,18 \\
\hline $\mathrm{CaO}$ & 5,21 & 0,30 & 0,58 & 0,35 & 3,49 & 0,21 & - & 7,13 & 0,92 \\
\hline $\mathrm{Na}_{2} \mathrm{O}$ & - & - & 0,13 & 0,2 & - & 0,01 & - & - & 0,17 \\
\hline $\mathrm{K}_{2} \mathrm{O}$ & - & - & - & - & - & 0,10 & - & - & - \\
\hline Сумма & 99,99 & 99,36 & 96,91 & 95,98 & 99,36 & 99,99 & 94,99 & 99,98 & 99,97 \\
\hline $\mathrm{Si}$ & 3,02 & 1,98 & 4,45 & 4,54 & 2,97 & 1,96 & 4,65 & 2,95 & 1,96 \\
\hline $\mathrm{Al}$ & 1,97 & 0,03 & 2,37 & 2,31 & 2,02 & 0,03 & 2,28 & 1,92 & 0,03 \\
\hline $\mathrm{Cr}$ & - & - & - & - & - & - & - & 0,01 & - \\
\hline $\mathrm{Fe}^{\prime \prime}$ & 2,25 & 1,34 & 0,11 & 0,12 & 2,31 & 1,38 & 0,07 & 2,15 & 1,45 \\
\hline $\mathrm{Mn}$ & 0,12 & 0,02 & 0,02 & - & 0,10 & 0,03 & - & 0,13 & 0,03 \\
\hline $\mathrm{Mg}$ & 0,19 & 0,61 & - & - & 0,26 & 0,61 & - & 0,20 & 0,51 \\
\hline $\mathrm{Ca}$ & 0,45 & 0,01 & 0,04 & 0,03 & 0,30 & 0,01 & - & 0,71 & 0,04 \\
\hline $\mathrm{Na}$ & - & - & - & 0,01 & - & - & - & - & 0,01 \\
\hline $\mathrm{K}$ & - & - & - & - & - & 0,01 & - & - & - \\
\hline $\mathrm{X}(\mathrm{Fe})^{* *}$ & 0,94 & 0,69 & - & - & 0,91 & 0,69 & - & 0,91 & 0,74 \\
\hline GOp**** & & & & & & & & & \\
\hline
\end{tabular}

* - символы минералов по [10]; ** - железистость минералов рассчитанная по отношению $\mathrm{Fe} /(\mathrm{Fe}+\mathrm{Mg})$; *** - гранат-ортопироксеновый геотермометр [14]

Клинопироксен присутствует в резко подчиненном количестве в виде агрегата тонких зерен (50-100 мкм) чаще всего в ассоциации с ортопироксеном и кварцем (рис. 2). Железистость клинопироксена соответствует 0,6-0,62 (в некоторых зернах до 0,64) при содержании $\mathrm{Al}_{2} \mathrm{O}_{3}=0,4-0,9$ мас. $\%$.

Плагиоклаз ксенобластовый, нередко с хорошо выраженными иногда деформированными (изгибающимися) двойниками. Минерал часто концентрируется в отдельных лейкократовых участках (линзах, полосах) в виде равномернозернистых агрегатов (рис. 2). Состав минерала разнообразен, и отражает, очевидно, как вариации первичного химизма пород, в том числе и локальные, так и последующие процессы кристал- 
логенеза. В целом, в исследованных образцах фиксируется практически весь возможный спектр составов минерала от битовнита с основностью $0,79-0,86$ до олигоклаза $0,15-0,21$.

Магнетит развит неравномерно в виде прослоев между зернами граната, кварца и орто-клинопироксенов. По химическому составу это практически чистый минерал с незначительными примесями $\mathrm{TiO}_{2}$ (1-2 мас.\%).

Кварц представлен крупными (0,5-1 мм) неправильными, реже изометричными зернами.

\section{Минеральные включения в гранате}

Минеральные включения в исследованных кристаллах граната представлены двумя типами: 1) твердофазные мономинеральные включения; 2) ретро- градные полиминеральные включения.

Твердофазные мономинеральные включения представляют собой реликты разнообразных минералов, законсервированные в матрице граната в результате его роста. Такие «классические» минеральные включения имеют размер преимущественно от 20 до 70 мкм, неправильную, реже овальную, и близкую к изометричной форму, и характеризуются широким диапазоном видового состава. В ходе микроскопических исследований в гранате были обнаружены твердофазные включения орто-клинопироксена, кварца, плагиоклаза, калиевого полевого шпата, ильменита, циркона (рис. 3а). Включения пироксенов содержат структуры распада твердых растворов, что косвенно подтверждает их первичную природу по отношению к кристаллам граната.
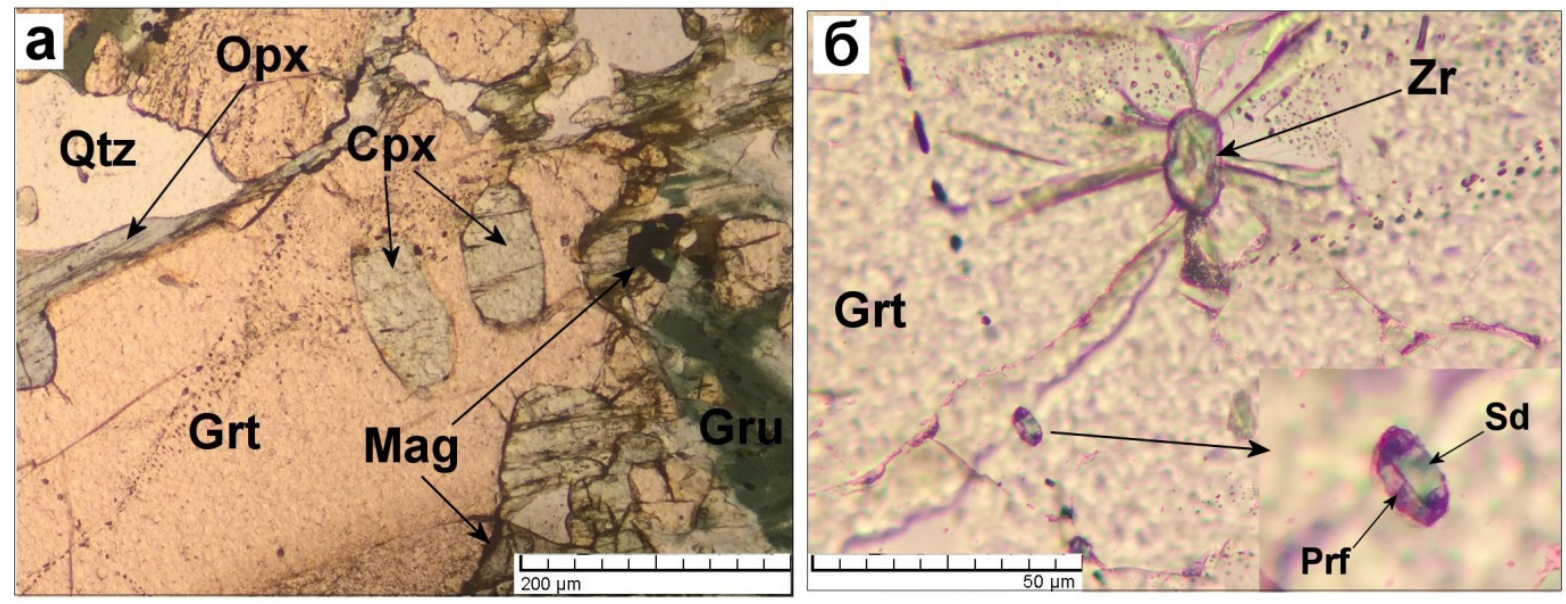

Puc. 3. Минеральные включения в гранатах: а - твердофазные мономинеральные включения клинопироксена; б - ретроградные полиминеральные включения, состоящие из сидерита и пирофиллита. В зерне граната присутствует также твердофазное включение циркона и мельчайшие газово-жидкие включения. Фотографии получены на оптическом микроскопе при одном николе. Символы минералов по [10].

Ретроградные полиминеральные включения - представляют собой многофазные системы, кристаллизованные при снижении температуры и давления за счет химических реакций между матричными минералами. Они отличаются от твердофазных мономинеральных включений выдержанной пропорцией фаз, т.е. количественные отношения фаз от включения к включению в пределах зерна минерала-хозяина постоянны. Если в минерале оказались случайные вростки, то пропорция фаз и их набор будут от включения к включению меняться. В полиминеральных включениях набор фаз и их пропорция определяется, главным образом, исходными составами реагирующих минералов (которые, как правило, выдержаны для одной генерации включений), а также составом флюида.

В исследованных зернах граната ретроградные полиминеральные включения представляют собой мелкие (от 1 до 20 мкм) агрегаты округлой и каплевидной формы, в некоторых случаях осложненные по периферии зонами расшнурования и декриптации (рис. 3б). Чаще всего это первично-вторичные включения, локализованные вдоль залеченных трещин, не выхо- дящих за границы минерала-хозяина [11].

Все обнаруженные полиминеральные включения в гранате состоят из двух минеральных фаз - сидерит и пирофиллит (рис. 4а-г). Кристаллы сидерита очень мелкие (5-10 мкм), в проходящем свете бесцветные и бледно-зеленоватые (за счет примеси $\mathrm{MnO}$ ) кристаллизованы на стенках камеры (рис. 3б). В их химическом составе помимо марганца отмечаются заметные примеси кальция и магния (табл. 2, рис.4е) Пирофиллит во включениях как бы оконтуривает кристаллы сидерита (рис. 3б, 4а-г). Он сложен мелкодисперсной (1-5 мкм) мягкой массой с отрицательным рельефом в шлифах. При поверхностном электронном сканировании в области нахождения пирофиллита наблюдаются дефекты поверхности («ямы»), связанные с выбиванием минерала при полировке шлифов. Тем не менее, в некоторых участках доступных для химического анализа был получен состав соответствующий $\mathrm{Al}_{2} \mathrm{Si}_{4} \mathrm{O}_{10}(\mathrm{OH})_{2}$ с незначительными примесями железа (табл. 1, рис. 4д). В большинстве случаев пирофиллит в пределах объема камеры включения превалирует над сидеритом с отношением 60/40\%. 

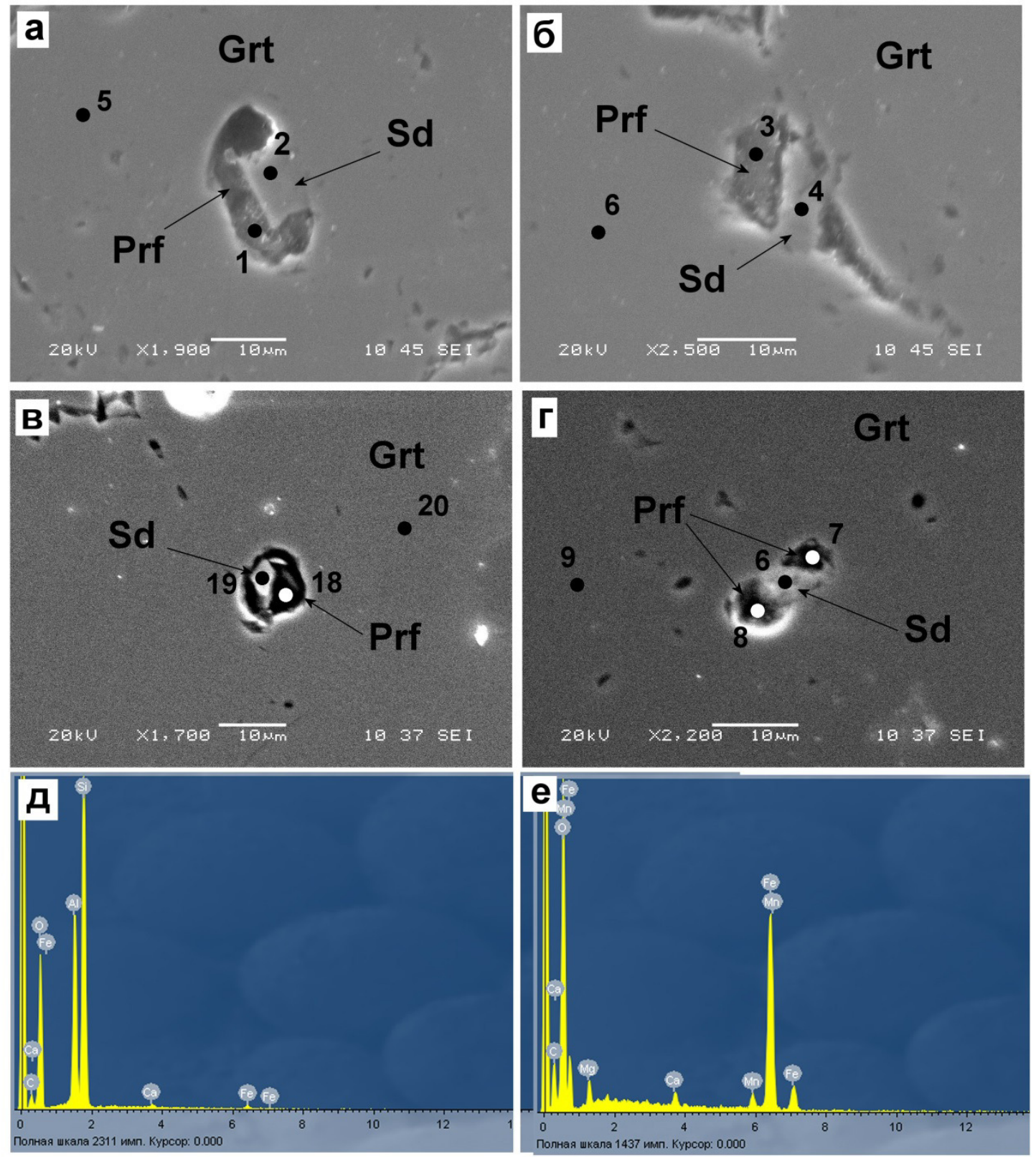

Puc. 4. Полиминеральные включения в ретроградном гранате: $a$ - первично-вторичное овальной формы (оно же на врезке рис. 3б); $\sigma$ - первичное-вторичное частично декриптированное неправильной формы; 8 - первичное округлой формы; 2 - первичное гантелевидной формы. $\partial$ - Рентгеновский спектр проанализированного пирофиллита (т.а. 1). $e$ - Рентгеновский спектр сидерита (т.а. 2). Изображения во вторичных электронах. Химические анализы представлены в таблице 1.

Таблица 2

Химические составы минеральных включений сидерита в гранатах

\begin{tabular}{|c|c|c|c|c|}
\hline Образец/Анализ & $193 / 2$ & $193 / 4$ & $189 / 19$ & $189 / 6$ \\
\hline $\mathrm{SiO}_{2}$ & 0,76 & - & 1,35 & 2,28 \\
\hline $\mathrm{Al}_{2} \mathrm{O}_{3}$ & - & - & 0,87 & 1,71 \\
\hline $\mathrm{Cr}_{2} \mathrm{O}_{3}$ & - & - & 0,69 & 0,29 \\
\hline $\mathrm{FeO}$ & 53,84 & 54,39 & 54,31 & 50,79 \\
\hline $\mathrm{MnO}$ & 3,47 & 2,5 & 1,25 & 1,97 \\
\hline $\mathrm{MgO}$ & 4,47 & 3,6 & 3,03 & 2,37 \\
\hline $\mathrm{CaO}$ & 1,56 & 1,4 & 0,96 & 2,73 \\
\hline $\mathrm{Na}_{2} \mathrm{O}$ & - & - & - & - \\
\hline $\mathrm{K}_{2} \mathrm{O}$ & - & - & - & - \\
\hline $\mathrm{Cумма}$ & 64,1 & 61,89 & 62,46 & 62,14 \\
\hline
\end{tabular}

\section{Интерпретация полученных результатов}

Кристаллизацию граната в регионально метаморфизованных железисто-кремнистых породах обогащенных глиноземом можно объяснить исходя из реакции 4Opx $+\mathrm{Pl}=>\mathrm{Grt}+\mathrm{Cpx}+\mathrm{Qtz}(1)$, протекающей c формированием структур уплотнения (например, коронарного граната (рис. 2)) и характеризующейся значительным отрицательным объемным эффектом $[12,13]$. Образование граната сопровождалось захватом минеральных и флюидных включений на ретроградном этапе метаморфизма при изобарическом остывании пород. Ранее $[12,13]$, на основе химических составов породообразующих минералов и набора аналитических данных по флюидным включениям 
были определены физико-химические условия кристаллизации граната со следующими усредненными по нескольким ассоциациям параметрами: $\mathrm{T}=615^{\circ} \mathrm{C}$, $\mathrm{P}=3,3$ кбар, $\mathrm{fO}_{2}=-18,8$ бар.

Термометрические оценки, полученные по мономинеральным твердофазным включениям, в целом, подтверждают эти значения: температура метаморфизма, полученная по ассоциации гранат-включения ортопироксена составляет (в среднем по нескольким образцам) $636 \pm 15^{\circ} \mathrm{C}$ (GOp геотермометр [14], табл. 1).

В гранате из глиноземисто-железистых пород ранее [4] были описаны различные типы флюидных включений (углекислотные, водно-солевые, метаназотные). Изученные полиминеральные включения, представлены карбонатной (сидерит) и алюмосиликатной водосодержащей (пирофиллит) фазой. Учитывая характер их локализации в пределах зерен граната (первично-вторичные), можно предположить, что они образовались на заключительных этапах кристаллизации граната при высокой активности метаморфического флюида (углекислоты и воды). Таким образом, реакция (1) с учетом полученных данных может быть скорректирована, и принять следующий вид: $\mathrm{Opx}+\mathrm{Pl}$ $+\mathrm{H} 2 \mathrm{O}+\mathrm{CO} 2=>\mathrm{Grt}+\mathrm{Sd}+\operatorname{Prf} \pm \mathrm{Cpx} \pm \mathrm{Mag}$.

К сожалению, в настоящее время отсутствуют надежные геотермометры, позволяющие определить температуру образования сидерит-пирофиллитовых ассоциаций, однако, исходя из экспериментальных данных [16] по синтезу алюмосиликатных систем насыщенных водой можно предположить, что пирофиллит-сидеритовая ассоциация будет устойчива при температурах от 350 до $550^{\circ} \mathrm{C}$ в широком диапазоне давлений. Таким образом, кристаллизация полиминеральных включений проходила на заключительных этапах ретроградной эволюции глиноземисто-железистых пород.

\section{Заключение}

Характер распределения минеральных включений в изученных кристаллах граната подтверждает корректность высказанной ранее гипотезы [16] о сложной полиметаморфической истории архейских железистокремнистых формаций Воронежского кристаллического массива с широким развитием низкотемпературных минеральных парагенезисов на заключительных этапах метаморфизма. Захват гранатом твердофазных мономинеральных включений соответствует этапу метаморфизма М3, а кристаллизация полиминеральных сидерит-пирофиллитовых включений отвечает заключительным низкотемпературным процессам в регионе и может рассматриваться как нижняя граница этапа метаморфизма М3.

\section{Воронежский государственный университет}

Пилюгин Сергей Михайлович, доцент кафедры полезных ископаемых и недропользования, кандидат геологоминералогических наук

E-mail: geoscience@yandex.ru; Тел.: 8 (473) 220-86-26
Благодарности. Автор благодарит к.г.-м.н. Лебедева И. П., а также к.г.-м.н. Терентьева Р. А. за весьма полезные и продуктивные замечания и предложения, сделанные при подготовке рукописи статьи.

Финансовая поддержка исследований осуществлялась Грантом РФФИ №16-05-01044.

\section{ЛИТЕРАТУРА}

1. Chopin, C. Coesite and pure pyrope in high-grade blueschists of the Western Alps: first record and some consequences / C. Chopin // Contr. Miner. Petrol. - 1984. - V.86. - P. 107-118.

2. Перчук, Л. Л. Глубинные ультракалиевые жидкости / Л. Л. Перчук, В. О. Япаскурт // Геология и геофизика. - 1998. - Т.39 (12). - C.1756-1765.

3. Пилюгин, С. М. Глиноземисто-железистые породы КурскоБесединского гранулитового блока ВКМ (физико-химические условия метаморфизма, тренд тектоно-термальной эволюции) / С. М. Пилюгин // Вестник Воронеж. гос. ун-та. Серия Геология. -2010 . - №2. - C.147-158.

4. Новикова, М. А. Флюидный режим метаморфизма архейской железисто-кремнистой формации Сарматии (по данным изучения флюидных включений) / М. А. Новикова, К. А. Савко // Труды НИИ Геологии. - 2010. - Выпуск 60.- 99 с.

5. Пилюгин, С. М. Высокотемпературный метаморфизм гранулитовых комплексов Сарматии / С. М. Пилюгин, К. А. Савко // Труды НИИ Геологии. - 2009. - Выпуск 54.- 106 с.

6. Gorbatschev, R. Frontiers in the Baltic Shield / R. Gorbatschev, S. Bogdanova // Precambrian Res. -1993. - V. 64. - P. 3-22.

7. Shchipansky, A. A. The Sarmatian crustal segment: Precambrian correlation between the Voronezh Massif and the Ukrainian Shield across the Dniepr-Donets Aulacogen / A. A. Shchipansky, S. V. Bogdanova // Tectonophysic. - 1996. - V. 268. - P. 109-125.

8. Возраст метаморфизма гранулитовых комплексов ВКМ: результаты U-PB геохронологических исследований монацита / К. А. Савко [и др.] // Доклады Академии наук. Сер. Геология. Москва, 2010. - Т. 435. - № 5. - С. 1-6.

9. Фонарев, В. И. Экспериментальные исследования равновесий с минералами переменного состава и геологическая термобарометрия / В. И. Фонарев, А. А. Графчиков, А. Н. Конилов // Экспериментальные проблемы геологии. - 1994. - С. 323-355.

10. Kretz, R. Symbols for rock-forming minerals / R. Kretz // Amer. Miner. - 1983. - V.68. - P. 277-279.

11. Roedder, E. Fluid inclusion / E. Roedder // Reviews in Mineralogy, 1984. - V. $12-644$ p.

12. Геря. Т. В. Термодинамический режим эволюции гранулитов Ангаро-Канского выступа / Т. В. Геря, Л. Л. Перчук // Вестник МГУ. Сер. Геол. - 1990. - N6. - С.35-49.

13. Perchuk, L. L. Petrology and retograde P-T-path in granulites of the Kanskaya formation, Enisey range, eastern Siberia / L. L. Perchuk, T. V. Gerya, A. D. Nozhkin // J.Metamorphic Geol. - 1989. V.7. - P. 599-617.

14. Perchuk. L. L. Some equilibria involving garnet, orthopyroxene and amphibole as geothermometers and geobarometers for metamorphic rocks / L. L. Perchuk, I. V. Lavrenteva // Experiment-89, Informative volume. - Moscow: Nauka. - 1990 - P. 44-45.

15. Roy. $R$. The system $\mathrm{Al}_{2} \mathrm{O}_{3}-\mathrm{SiO}_{2}-\mathrm{H}_{2} \mathrm{O} /$ R. Roy, E. F.Osborn // Am. Mineral. - 1954. -V.39-853 p.

16. Exsolution Textures of ortho- and clinopyroxene in high-grade BIF of the Voronezh Crystalline Massif: Evidence of ultrahightemperature metamorphism / V. I. Fonarev [et al.] // J. metamorphic Geol. - 2006. - V. 24. - P. 135-151.

\section{Voronezh State University}

Pilugin S. M., lecturer of mineral resource department, Candidate of Geological and Mineralogical Sciences

E-mail: geoscience@yandex.ru

Tel.: 8 (473) 2208626 